\title{
Body Weight Reason Not Done
}

National Cancer Institute

\section{Source}

National Cancer Institute. Body Weight Reason Not Done. NCI Thesaurus. Code C119788.

The explanation given as to why body weight was not assessed. 